\title{
Analisis Perbedaan Abnormal Return, Volume Perdagangan Saham Sebelum dan Sesudah Pengumuman Corporate Image Award
}

\author{
Robert Jao ${ }^{1)}$, David Jimmiawan ${ }^{2)}$ \\ Email: jao_robert@hotmail.com ${ }^{1}$, davidjimmiawann@gmail.com $^{2)}$
}

\author{
${ }^{1}$ Dosen Prodi Akuntansi, Universitas Atma Jaya Makassar
}

(Diterima: 1 Juli 2018; di revisi: 28 Agustus-2018; dipublikasikan: 31 Oktober-2018)

\begin{abstract}
Abstrak:
Penelitian ini bertujuan untuk mengetahui apakah ada perbedaan abnormal return dan volume perdagangan saham sebelum dan sesudah pengumuman Corporate Image Award. Reaksi padar diukur dengan abnormal return dan volume perdagangan saham. Sampel yang digunakan dalam penelitian ini adalah semua perusahaan yang menerima penghargaan Corporate Image Award yang terdaftar di Bursa Efek Indonesia periode 2015, 2016, dan 2017. Penelitian ini menggunakan studi peristiwa untuk menguji adanya reaksi pasar pada periode pengamatan, yaitu lima hari sebelum dan lima hari sesudah pengumuman dengan menggunakan model sesuaian pasar untuk menghitung return ekpektasian. Data yang digunakan dalam penelitian ini menggunakan data sekunder yaitu harga penutupan saham harian dan volume perdagangan saham harian. Metode Statistik yang digunakan untuk menguji hipotesis adalah Wilcoxon Signed Test. Hasil penelitian ini membuktikan bahwa tidak terdapat perbedaan yang abnormal return dan volume perdagangan saham sebelum dan sesudah pengumuman Corporate Image Award periode 2015, 2016, dan 2017.
\end{abstract}

Kata-kata Kunci : Studi peristiwa, Corporate Image Award, abnormal return, and trading volume activity.

\begin{abstract}
:
This research aims to investigate if there was difference in abnormal return and trading volume activity before and after the announcement of Corporate Image Award. The market reaction is measured by abnormal return and trading volume activity. The sampel used in this research are all companies which accept the appreciation of Corporate Image Award that listed in Indonesian Stock Exchange (IDX) in 2015, 2016, and 2017 period. This research uses event study to show market reactions arount the event period, at five days before and after the announcement by used a market adjusted model for expected return. The research data that used is secondary data that consist of daily closing price of shares and daily and daily trading volume activity. The statistic method used to test the hypotheses was Wilcoxon Signed Test. The results of this research proves that there is no difference abnormal return and trading volume activity before and after Corporate Image Award announcement.
\end{abstract}

Keywords : Event study, Corporate Image Award, abnormal return, and trading volume activity.

\section{PENDAHULUAN}

Perusahaan senantiasa menjaga pandangan atau persepsi publik baik dari pihak - pihak yang ada di dalam maupun di luar perusahaan (Miles dan Covin, 2000). Pandangan atau persepsi itu muncul dari tindakan atau apa yang perusahaan lakukan, salah satunya kemampuan perusahaan dalam menciptakan hal-hal yang baru yang dapat meningkatkan keuntungan yang akan meningkatkan minat investor dalam berinvestasi (Herbig dan Milewicz, 1993). Qurani (2011) juga menyatakan bahwa perusahaan yang melakukan tanggung jawab sosialnya serta peduli terhadap lingkungan perusahaan tersebut akan meningkatkan pandangan positif publik mengenai perusahaan tersebut di mana didukung juga oleh Astiti dan Saitri (2016) serta Saputri (2010) yang menemukan hubungan positif antara CSR dan Corporate Image. Sebagai bentuk apresiasi kepada perusahaan yang telah berusaha 
meningkatkan kualitas, kinerja, tanggung jawabnya sebagai perusahaan serta melakukan tindakan-tindakan seperti salah satunya kegiatan Corporate Social Responsibility dalam rangka untuk menarik minat serta meningkatkan persepsi atau pandangan masyarakat, pelanggan dan calon investor untuk meningkatkan corporate image maka Frontier Consulting Group menyelenggarakan Corporate Image Award Penyerahan award seperti ini akan membuat perusahaan terpicu untuk mencari cara untuk meningkatkan kualitas pelayanan yang akan berdampak pada kepuasaan pelanggan dan loyalitas pelanggan sehingga Corporate Image perusahaan melalui persepsi masyarakat serta calon investor dapat meningkat seiring dengan pengumuman pemenang dari Corporate Image Award ini.

Menurut Akis dan Mutmainah (2012) serta Purnawasari (2017), abnormal return adalah selisih antara return yang sesungguhnya dengan return ekspektasi. Peningkatan return merupakan reaksi positif dari pasar yang digambarkan dengan peningkatan harga saham. Reaksi tersebut biasanya diukur dengan menggunakan abnormal return (Budiman, 2009 dalam Akis dan Mutmainah, 2012). Apabila pengumuman Corporate Image Award dianggap sebagai informasi yang positif maka investor akan mempertimbangkan dalam pengambilan keputusan yang akan sejalan dengan kenaikan pembelian saham perusahaan dan akan meningkatkan harga saham sekuritas tersebut atau dianggap sebagai abnormal return yang positif (Budiman, 2009 dalam Akis dan Mutmainah, 2012).

Beberapa penelitian yang meneliti apakah terdapat reaksi dari pasar atas suatu pengumuman salah satunya oleh Budiman dan Supatmi (2009) menemukan perbedaan yang signifikan terhadap abnormal return sebelum dan sesudah pengumuman Indonesian Sustainability Reporting Award (ISRA), tetapi volume perdagangan saham tidak menunjukkan perbedaan. Sedangkan, Purnawasari (2017) yang penelitiannya menunjukkan bahwa tidak ada perbedaan sebelum dan sesudah pengumuman Indonesian Sustainability Reporting Award (ISRA) periode 2012-2016 terhadap reaksi pasar.

Event dalam penelitian ini berupa Corporate Image Award (CIA) periode 2015, 2016 dan 2017.

Studi Peristiwa (Event Study)
Studi peristiwa (event study) merupakan sebuah metode studi yang mempelajari reaksi pasar atas sebuah informasi yang berasal dari suatu pengumuman. Menurut Jogiyanto (2017), studi peristiwa (event study) merupakan studi yang mempelajari reaksi pasar terhadap suatu peristiwa (event) yang informasinya dipublikasikan sebagai suatu pengumuman. Jika menggunakan abnormal return, pengumuman yang memiliki kandungan informasi akan memberikan abnormal return pada saat setelah pengumuman tersebut diterima di pasar, sebaliknya jika pengumuman tersebut tidak mengandung informasi maka tidak akan memberikan abnormal return terhadap pasar pada saat setelah pengumuman tersebut diterima (Jogiyanto, 2017; Akis dan Mutmainah, 2012).

\section{Corporate Image Award}

Corporate Image Award penting karena perusahaan yang mendapatkan award tersebut bisa mendapatkan keuntungan dari laporan penelitian Corporate Image yaitu untuk mengidentifikasi kekuatan dan kelemahan Corporate Image berdasarkan 4 dimensi dasar: kualitas, kinerja, tanggung jawab, dan daya tarik di dalam pikiran masing-masing pemangku kepentingan, termasuk Publik, Manajemen, Investor dan Wartawan. Untuk mengukur posisi Corporate Image perusahaan dibandingkan dengan perusahaan lain di dalam industri yang sama (imacaward.com).

\section{Abnormal Return}

Tujuan utama investor dalam melakukan investasi adalah mendapatkan keuntungan seoptimal mungkin (Purnawasari, 2017; Mila, 2010). Keuntungan yang didapatkan tersebut dapat berupa return yang sesungguhnya dengan return yang diharapkan (ekpektasi). Selisih antara return yang benar-benar terjadi dengan return (Ang, 1977 dalam Mila, 2010; Jogiyanto, 2017).

Jika tingkat pengembalian (return) yang diterima investor melebihi tingkat pengembalian (return) yang diharapkan maka hal itu menunjukkan abnormal return yang positif dan dengan kata lain investor menerima keuntungan yang lebih besar daripada apa yang ia harapkan, sedangkan jika tingkat pengembalian (return) yang investor terima lebih kecil dengan tingkat pengembalian (return) yang investor harapkan maka hal tersebut menunjukkan abnormal return yang negatif (Mila, 2010; Jogiyanto, 2017). 
Berdasarkan pemaparan di atas, maka dilakukan penelitian dengan tujuan untuk menguji perbedaan reaksi pasar berupa abnormal return dan volume perdagangan saham sebelum dan sesudah pengumuman.

\section{METODE}

\section{Pendekatan Penelitian}

Pendekatan penelitian yang digunakan dalam penelitian ini adalah pendekatan deskriptif kuantitatif. Santoso (2012) menjelaskan pendekatan deskriptif kuantitatif merupakan penelitian dengan mendeskripsikan secara sistematis, faktual dan akurat terhadap kondisi dan fenomena yang terjadi berdasarkan data dan informasi yang didapatkan dalam penelitian. Dalam penelitian ini, digunakan metode kuantitatif karena angka, mulai dari pengumpulan data, penafsiran data tersebut, serta menampilkan hasilnya. Selain itu juga akan digunakan tabel, grafik dan diagram.

\section{Populasi dan Sampel}

Populasi yang diambil dalam penelitian ini adalah seluruh perusahaan pemenang Corporate Image Award (CIA) dari tahun 2015, 2016, dan 2017. Teknik pengambilan sampelnya menggunakan teknik purposive sampling. Ketentuan-ketentuan dalam pengambilan sampel dalam penelitian ini adalah :

1. Perusahaan-perusahaan pemenang Corporate Image Award (CIA) pada tahun 2015, 2016, dan 2017.

2. Perusahaan pemenang award tersebut listing di Bursa Efek Indonesia pada tahun 2015, 2016, dan 2017.

\section{Metode Pengumpulan Data}

Metode pengumpulan data dalam penelitian ini adalah dokumentasi. Data sehubungan dengan penelitian ini adalah daftar pemenang Corporate Image Award tahun 2015,
2016 dan 2017 yang dapat dilihat di website www.imacaward.com serta data mengenai perubahan harga saham dan perubahan volume perdagangan yang dapat dilihat di website resmi Bursa Efek Indonesia www.idx.co.id atau website sehubungan dengan data Bursa Efek Indonesia.

\section{Metode Analisis Data}

Dalam penelitian ini uji normalitas yang digunakan adalah uji One Sample KolmogorovSmirnov dengan menggunakan taraf signifikansi 0,05 . Data dinyatakan berdistribusi normal jika signifikansi lebih besar dari $5 \%$ atau 0,05 . Uji normalitas menunjukkan tingkat signifikansi abnormal return sebelum pengumuman menunjukkan angka 0,00 yang berarti di bawah nilai probabilitas yaitu 0,05 . Hal ini mengindikasikan bahwa data tidak berdistribusi normal dan tingkat signifikansi abnormal return sesudah pengumuman menunjukkan angka $0,193>0,05$ yang berarti $\mathrm{H} 0$ diterima atau data telah terdistribusi secara normal. Sedangkan, tingkat signifikansi volume perdagangan saham sebelum dan sesudah pengumuman sama-sama menunjukkan tingkat signifikansi $0,00<0,05$ yang berarti bahwa H0 ditolak atau data tidak terdistribusi secara normal. Pengujian hipotesis tidak dapat menggunakan uji parametric yaitu uji$\mathrm{t}$ berpasangan (paired sample t-test) meskipun dalam hal ini syarat untuk menggunakan uji-t berpasangan terpenuhi yaitu sampel di atas 30 perusahaan. Oleh karena hal itu, alternatif lain agar data yang telah dikumpulkan tetap dapat diuji atau di analisis adalah dengan menggunakan metode statistik non parametric yaitu dengan menggunakan uji beda rata-rata Wilcoxon Signed Test.

\section{HASIL DAN PEMBAHASAN}

\section{Analisis Data}

Analisis dilakukan dengan cara membandingkan nilai dari masing masing variabel ada periode sebelum dan sesudah peristiwa, yang mana periodenya adalah lima hari sebelum peristiwa dan lima hari sesudah peristiwa. Dalam Penelitian ini data yang digunakan adalah rata-rata abnormal return dan volume perdagangan saham pada perusahaan pemenang CIA 2015, 2016 dan 2017, dengan periode penelitian lima hari sebelum ( $t-5$ sampai dengan $\mathrm{t}-1)$ dan lima hari sesudah $(\mathrm{t}+1$ sampai dengan $\mathrm{t}+5$ ) tanggal pengumuman CIA. Tanggal 
pengumuman CIA untuk tahun 2015 adalah 11 Juni 2015, untuk tahun 2016 adalah 9 Juni 2016 dan untuk tahun 2017 adalah 9 Juni 2017.

\section{Data Abnormal Return}

Pada tahun 2015 dari total 36 perusahaan terdapat 17 perusahaan diantaranya mengalami peningkatan abnormal return sedangkan 19 perusahaan lainnya mengalami penurunan, pada tahun 2016 dari total 36 perusahaan terdapat 25 perusahaan mengalami peningkatan abnormal return dan 11 perusahaan lainnya mengalami penurunan, dan pada tahun 2017 dari total 34 perusahaan terdapat 17 perusahaan yang mengalami kenaikan abnormal return dan 17 perusahaan lainnya mengalami penurunan.

\section{Data Volume Perdagangan Saham}

Pada tahun 2015 dari total 36 perusahaan terdapat 10 perusahaan yang mengalami kenaikan volume perdagangan saham dan 26 perusahaan mengalami penurunan, pada tahun 2016 dari total 36 perusahaan terdapat 11 perusahaan mengalami kenaikan volume perdagangan saham, 24 perusahaan mengalami penurunan dan 1 perusahaan yang volume perdagangan sahamnya tidak mengalami kenaikan maupun penurunan, pada tahun 2017 dari total 34 perusahaan terdapat 18 perusahaan yang mengalami kenaikan volume perdagangan saham, 14 perusahaan mengalami penurunan dan 2 perusahaan yang volume perdagangan sahamnya tidak mengalami kenakan maupun penurunan.

\section{Uji Wilcoxon Signed Test}

Pengujian hipotesis yang digunakan dalam penelitian ini adalah uji non parametric yaitu uji beda rata-rata Wilcoxon Signed Test. Tujuan dari pengujian ini ialah untuk melihat apakah ada perbedaan pada abnormal return dan volume perdagangan saham sebelum dan sesudah pengumuman CIA 2015, 2016 dan 2017. Tingkat keyakinan yang digunakan pada penelitian ini adalah (1- $\alpha)$ sebesar 95\% dengan tingkat signifikansi $5 \%(0,05)$. Data yang digunakan diolah menggunakan program SPSS 21 dan Microsoft Excel.

Berdasarkan hasil pengolahan data yang dilakukan dengan menggunakan SPSS versi 21, hasil uji beda rata-rata Wilcoxon Signed Test dapat dilihat pada tabel di bawah ini:

Tabel 1.

Hasil Uji Wilcoxon Signed Test

\begin{tabular}{|c|c|c|}
\hline & $\begin{array}{c}\text { ARsesudah - } \\
\text { ARsebelum }\end{array}$ & $\begin{array}{c}\text { TVAsebelum - } \\
\text { TVAsesudah }\end{array}$ \\
\hline $\mathrm{Z}$ & $-1,351$ & $-1,547$ \\
\hline $\begin{array}{c}\text { Asymp. } \\
\text { Sig. (2- } \\
\text { tailed) }\end{array}$ & 0,177 & 0,122 \\
\hline
\end{tabular}

Sumber : Data diolah SPSS (2018).

Dari hasil pengujian Wilcoxon Signed Test di atas, diperoleh:

1. Nilai signifikansi untuk rata-rata abnormal return sebesar 0,177 yang berarti bahwa nilainya di atas nilai alpha 0,05 sehingga memberikan hasil Ho diterima dan $\mathrm{Ha}$ ditolak yang mengartikan tidak ada perbedaan abnormal return sebelum dan sesudah pengumuman CIA 2015, 2016 dan 2017.

2. Nilai signifikansi untuk rata-rata volume perdagangan saham sebesar 0,122 yang nilainya juga berada di atas nilai alpha 0,05 dan memberikan kesimpula bahwa Ho diterima dan $\mathrm{Ha}$ ditolak yang mengindikasikan tidak ada perbedaan volume perdagangan saham sebelum dan sesudah pengumuman CIA 2015, 2016 dan 2017.

\section{Pembahasan Hasil Penelitian \\ Perbedaan Abnormal Return Sebelum dan Sesudah Pengumuman Corporate Image Award 2015, 2016 dan 2017}

Hasil pengujian hipotesis melalui Wilcoxon Signed Test diperoleh nilai signifikansi rata-rata abnormal return sebesar 0,177 yang berarti di atas nilai alpha 0,05 sehingga dari penelitian ini memberikan hasil bahwa hipotesis pertama (H1) yang menyatakan terdapat perbedaan abnormal return sebelum dan sesudah pengumuman Corporate Image Award 2015, 2016 dan 2017 ditolak. Hal ini menunjukkan kandungan informasi pada pengumuman Corporate Image Award 2015, 2016 dan 2017 tidak di respon oleh investor.

Investor menganggap bahwa informasi tersebut masih kurang relevan dan belum sepenuhnya dianggap sebagai good news untuk dijadikan dasar pengambilan keputusan investasi oleh investor dan calon investor. Walaupun terjadi perubahan pada abnormal return tetapi perubahan itu sangat kecil dan selain itu terdapat juga abnormal return yang bernilai negatif setelah tanggal pengumuman CIA 2015, 2016 dan 2017. Hal ini mengindikasikan bahwa 
pengumuman CIA tidak mengandung informasi sehingga memengaruhi keputusan investor.

Hasil penelitian ini sejalan dengan penelitian Purnawasari (2017) yang menyatakan tidak adanya perbedaan reaksi pasar yang diukur melalui abnormal return dan volume perdagangan saham pada perusahaan pemenang ISRA 2012-2016. Penelitian ini juga memiliki hasil yang sama yang dihasilkan oleh Apriyanti dan Sidanti (2016) yang menyimpulkan tidak terdapatnya perbedaan abnormal return pada perusahaan pemenang ARA, ICA dan ISRA periode 2014. Akan tetapi, hasil penelitian ini berbeda dengan hasil yang didapatkan oleh Budiman dan Supatmi (2009) yang menemukan perbedaan yang signifikan terhadap abnormal return sebelum dan sesudah pengumuman (ISRA) tahun 2005- 2008. Supatmi dan Idealfa (2011) juga menemukan perbedaan abnormal return pada perusahaan pemenang Indonesian CSR Award periode 2005 dan 2008.

Tidak adanya perbedaan yang signifikan pada saat sebelum dan setelah pengumuman award disebabkan berita mengenai pengumuman award ini tidak sampai ke mayoritas investor karena informasi mengenai award ini sendiri kurang di publikasikan oleh media-media berita yang ada di indonesia. Hal tersebut dibuktikan dengan tidak terjadinya perubahan yang cukup besar nilai abnormal return pada mayoritas perusahaan yang terjadi pada event window, bahkan ada juga beberapa perusahaan yang mengalami penurunan nilai return sahamnya setelah hari pengumuman juga terdapat beberapa perusahaan yang tidak mengalami perubahan nilai return sahamnya sama sekali, selain itu faktor penentuan pemenang award yang diberikan tidak hanya untuk perusahaan yang terdaftar pada Bursa Efek Indonesia atau dengan kata lain bahwa pemenang dari award ini diberikan kepada perusaahan go public dan non go public.

\section{Perbedaan Volume Perdagangan Saham Sebelum dan Sesudah Pengumuman Corporate Image Award 2015, 2016, dan 2017}

Hasil pengujian hipotesis melalui Wilcoxon Signed Test diperoleh nilai signifikansi rata-rata volume perdagangan saham 0,122 yang berarti di atas nilai alpha 0,05 sehingga hasil pengujian yang dilakukan terhadap volume perdagangan saham pada saat sebelum dan sesudah pengumuman CIA 2015, 2016 dan 2017 menyatakan tidak ada perbedaan sehingga hipotesis yang menyatakan terdapat perbedaan volume perdagangan sebelum dan sesudah pengumuman CIA ditolak.

Tidak terbuktinya hipotesis kedua ini mengindikasikan bahwa pengumuman CIA 2015, 2016 dan 2017 mungkin kurang menarik perhatian investor dalam pengambilan keputusan investasi karena volume perdagangan saham merupakan indikator yang digunakan untuk melihat besarnya minat investor terhadap suatu saham. Selain itu, terdapat juga kemungkinan bahwa investor masih berorientasi pada kinerja jangka pendek dan manfaat yang bersifat jangka panjang belum di pertimbangkan oleh investor.

Hasil dari penelitian ini juga memberikan hasil yang sama dengan Randa dan Wiese (2012) yang menemukan tidak adanya perbedaan volume perdagangan saham sebelum dan sesudah pengumuman Indonesian CSR Awards 2011. Jao (2016) juga menyimpulkan tidak adanya perbedaan volume perdagangan saham sebelum dan sesudah pengumuman Indonesian CSR Award 2014. Akan tetapi, hasil dari penelitian ini bertentangan dengan hasil yang ditemukan oleh Syahbana (2014) yang menemukan perbedaan yang signifikan volume perdagangan saham sebelum dan sesudah pengumuman ARA 2011-2012.

Berdasarkan data di atas, tidak adanya perbedaan pada volume perdagangan saham ini dapat disebabkan oleh beberapa hal. Salah satunya dikarenakan informasi mengenai pengumuman award ini tidak sampai ke para calon investor dan investor karena masih kurang di publikasikan oleh media-media berita yang ada di indonesia. Hasil menunjukkan bahwa pada beberapa perusahaan memiliki nilai nol pada jumlah volume perdagangan sahamnya atau dapat dikatakan sahamnya tidur karena harga sahamnya tidak mengalami perubahan dalam jangka waktu yang panjang dan tidak adanya transaksi saham yang terjadi pada perusahaan tersebut pada beberapa hari selama event window. Nilai nol tersebut terjadi disebabkan karena masih kurangnya perhatian yang diberikan dari para investor kepada perusahaanperusahaan pemenang award tersebut. Hal tersebut menyatakan bahwa pemenang award yang dinilai memiliki image yang baik diantara para pesaingnya pada bidang yang sama yang telah dinilai oleh suatu badan profesional di bidangnya masih kurang menarik perhatian para investor untuk dijadikan dasar dalam pengambilan keputusan investasi, salah satu faktor yang menyebabkan hal tersebut dapat terjadi karena award ini diberikan tidak hanya 
bagi perusahaan yang terdaftar di BEI tetapi juga untuk perusahaan yang tidak terdaftar di BEI sehingga investor menganggap pengumuman ini kurang relevan untuk digunakan sebagai dasar pengambilan keputusan.

\section{KESIMPULAN, DAN SARAN}

\section{Kesimpulan}

Berdasarkan analisis dan pengujian data serta pembahasan hasil penelitian yang telah dibahas sebelumnya maka dapat diambil kesimpulan sebagai berikut:

1. Abnormal Return sebelum dan sesudah pengumuman Corporate Image Award 2015, 2016 dan 2017 tidak terdapat perbedaan pada perusahaan pemenang award.

2. Volume Perdagangan Saham pada event window 5 hari sebelum dan 5 hari sesudah pengumuman juga menemukan tidak adanya perbedaan pada perusahaan pemenang Corporate Image Award 2015, 2016 dan 2017.

\section{Saran}

Beberapa saran bagi penelitian yang akan datang, antara lain memilih ajang penghargaan yang para pemenangnya hanya yang terdaftar di Bursa Efek Indonesia sehingga investor dapat lebih menggunakan penghargaan tersebut untuk membandingkan antara suatu perusahaan dan perusahaan yang lainnya sehingga dapat dijadikan dasar pengambilan keputusan investasi, memilih event penghargaan yang informasinya disebar secara luas baik melalui media koran maupun website media berita Indonesia sehingga informasi tersebut dapat sampai dengan baik kepada investor sehingga dapat dijadikan salah satu dasar pengambilan keputusan investasi. Penelitian berikutnya juga dapat mengukur reaksi pasar dengan menggunakan frekuensi perdagangan saham.

\section{DAFTAR PUSTAKA}

Akis, A. R., \& Mutmainah, S. (2012). Pengaruh Pengumuman Indonesia Sustainability Reporting Award (ISRA) terhadap Abnormal Return dan Volume perdagangan Saham (Studi Kasus pada Perusahaan Peraih Penghargaan ISRA 2009-2010). Jurnal Akuntansi dan Auditing.

Apriyanti, \& Sidanti, H. (2016). Perbedaan Abnormal Return dan Volume Perdagangan Saham sebelum dan setelah pengumuman
Pemenang Award Tahun 2014 pada perusahaan yang listing di Bursa Efek Indonesia. Ekuilibrium: Jurnal Ilmiah Bidang Ilmu Ekonomi Volume 11, No 2, September 2016.

Astiti, N. Y. \& Saitri, P. W. (2016). Pengaruh Corporate Social Responsibility terhadap Kesejahteraan Masyarakat dan Citra Perusahaan. Jurnal Bisnis Dan Kewirausahaan Vol.12. No.2 Juli 2016.

Budiman, F., \& Supatmi. (2009). Pengaruh Pengumuman Indonesia Sustainability Reporting Award (ISRA) terhadap Abnormal Return dan Volume Perdagangan Saham (Studi Kasus pada Perusahaan Pemenang ISRA 2005-2008).

Erasaputranto, R. A. \& Hermawan, A. (2015). The Effect of Corporate Image on Company's Stock Return.

Firmansyah, H. \& Hadijono, S. (2016). Analisis Pengaruh Volume Perdagangan Saham terhadap Return Saham pada Perusahaan Peraih Penghargaan Annual Reporting Award (ARA) Tahun 2014. JURNAL EKONOMI AKUNTANSI Volume 1, Nomor 1, April 2016, 83-96.

Herbig, P. \& Milewicz, J. (1993). The Relationship of Reputation and Credibility to Brand Success. Journal of Consumer Marketing, Vol. 10 No. 3, 1993, 18-24.

Jao, R. (2016). Analisis perbedaan Harga Saham dan Volume Perdagangan Saham sebelum dan sesudah Pengumuman Indonesian CSR Award.

Jogiyanto, H. (2017). Teori Portofolio dan Analisis Investasi. Yogyakarta: BPFEYogyakarta.

Mila, I. A. (2010). Analisis Pengaruh Pemecahan Saham (Stock Split) terhadap Volume Perdagangan Saham dan Abnormal Return Saham pada perusahaan yang terdaftar di BEI tahun 2007-2009.

Miles, M. P. \& Covin, J. G. (2000). Environmental Marketing:A Source of Reputational, Competitive, and Financial Advantage. Journal of Business Ethics.

Purnawasari, H. (2017). Analisis perbedaan Reaksi Pasar sebelum dan sesudah Pengumuman Indonesia Sustainability Reporting Award (ISRA) (Studi Kasus pada Perusahaan Penerima Penghargaan ISRA periode 2012-2016).

Randa, F. \& Liman, W. (2012). Analisis perbedaan Abnormal Return dan Volume Perdagangan Saham sebelum dan sesudah 
Robert Jao dan David Jimmiawan, Analisis Perbedaan Abnormal Return, Volume Perdagangan Saham Sebelum dan Sesudah Pengumuman Corporate Image Award. | 31

Pengumuman Indonesian CSR Awards (Studi kasus pada perusahaan pemenang ICA yang terdaftar di BEI tahun 2011). Jurnal Sistem Informasi Manajemen dan Akuntansi Vol 10 No.2 Oktober 2012 Fakultas Ekonomi UAJ Makassar, 151 168.

Rita, M. R. (2009). Pengaruh Hari Perdagangan terhadap Return Saham. Jumal Ekonorni dan Bisnis Vol. XV No.2 September 2009, 121-134.

Saputri, N. (2010). Analisis Corporate Social Responsibility sebagai pembentuk citra perusahaan dan pengaruhnya terhadap loyalitas pelanggan.

Supatmi \& Idealfa, N. D. (2011). Dampak Indonesia Corporate Social Respnsibility Award (ICA) terhadap Abnormal Return dan Trading Volume Activity.

Syahbana, F. K. (2014). Perbandingan Harga Saham dan Volume Perdagangan Saham sebelum dan sesudah Pengumuman Annual Report Award (Studi pada perusahaan go public pemenang ARA 2011-2012).

www.finance.yahoo.com

www.idx.com

www.sahamok.com

www.imacaward.com 